\title{
PERSEPSI DAN POLA ADAPTASI MASYARAKAT TELUK POPOH TERHADAP PERUBAHAN IKLIM
}

\section{Perception and Adaptation Pattern of Popoh Bay Community toward Climate Change}

\author{
Andik Isdianto ${ }^{1,2}$, Oktiyas Muzaky Luthfi ${ }^{1,2}$ \\ Diterima: 30 Juli 2019, Disetujui: 2 November 2019
}

\author{
${ }^{1}$ Program Studi Ilmu Kelautan, Universitas Brawijaya \\ ${ }^{2}$ Coastal Resilience and Climate Change Adaptation, Universitas Brawijaya \\ Jl. Veteran Malang, Ketawanggede, Kec. Lowokwaru, Kota Malang, Jawa Timur 65145 \\ Corresponding Author; \\ Andik Isdianto \\ e-mail : andik.isdianto@ub.ac.id
}

\begin{abstract}
ABSTRAK
Perubahan iklim memberikan dampak yang besar di berbagai negara. Adapun dampak dari terjadinya perubahan iklim adalah bertambahnya intensitas kejadian cuaca ekstrim di suatu wilayah, perubahan pola hujan, serta peningkatan suhu dan permukaan air laut Dampak perubahan iklim dapat memengaruhi keadaan di daratan maupun di pesisir atau laut. Salah satu wilayah di Provinsi Jawa Timur yang terkena dampak perubahan iklim yang mengkhawatirkan adalah wilayah Teluk Popoh yang terletak di Desa Besole, Kecamatan Besuki, Kabupaten Tulungagung, Provinsi Jawa Timur. Kerusakan yang terjadi di perairan pantai Sidem berupa perubahan garis pantai yang disebabkan oleh bertambah tingginya permukaan air laut serta adanya aliran sungai Neyama yang langsung bermuara di pantai Sidem, Teluk Popoh. Hal lain yang disebabkan oleh perubahan garis pantai di Teluk Popoh adalah rusaknya sumberdaya alam di perairan Teluk Popoh, dimana nelayan dan masyarakat pesisir Teluk Popoh akan semakin sulit untuk mencari ikan di perairan sekitar. Untuk menghindari terjadinya dampak perubahan iklim yang berkelanjutan, maka PLTA Tulungagung yang beroperasi di wilayah pantai Sidem Teluk Popoh dan pemerintah Kabupaten Tulungagung memberikan inisiatif berupa penanaman pohon dan mangrove di wilayah Pantai Teluk Popoh. Dengan upaya mitigasi tersebut diharapkan mengurangi dampak yang diberikan oleh perubahan iklim di Teluk Popoh. Mitigasi tersebut tidak akan berjalan tanpa adanya usaha adaptasi dari masyarakat sekitar Teluk Popoh. Masyarakat di Desa Besole merupakan masyarakat yang didominasi oleh para nelayan yang kehidupannya sangat bergantung pada keberadaan laut. Apabila terjadi perubahan iklim di laut, maka para nelayan dari Desa Besole perlu beradaptasi terhadap perubahaan iklim tersebut..
\end{abstract}

Kata kunci: perubahan iklim; persepsi masyarakat; pola adaptasi.

\begin{abstract}
Climate change has a large impact in various countries. The impact of climate change is the increase in the intensity of extreme weather events in an area, changes in rainfall patterns, and an increase in sea water temperature and surface. The impact of climate change can affect conditions on land or on the coast or the sea. One area in East Java Province that is affected by climate change that is worrying is the Popoh Bay area which is located in Besole Village, Besuki District, Tulungagung Regency, East Java Province. Damage that occurred in the waters of Sidem beach in the form of changes in the coastline caused by rising sea levels and the flow of the Neyama River which immediately empties into Sidem Beach, Popoh Bay. Another thing caused by changes in the coastline in Popoh Bay is the destruction of natural resources in the waters of Popoh Bay, where fishermen and the coastal communities of Popoh Bay will find it increasingly difficult to find fish in their waters. To avoid the impact of sustainable climate change, the Tulungagung Hydroelectric Power Plant operating in the Pantai Sidem Bay area of Popoh Bay and the Tulungagung Regency government provided initiatives in the form of planting trees and mangroves in the Pantai Popoh Bay area. The mitigation effort is expected to reduce the impact of climate change in Popoh Bay. The mitigation will not proceed smoothly without any adaptation efforts from the communities around the Gulf of Popoh. The community in Besole Village is a community dominated by fishermen whose lives depend heavily on the presence of the sea. If climate change occurs at sea, the fishermen from Besole Village will need to adapt to the climate change.
\end{abstract}

Keywords: climate change; community perception; adaptation pattern.

\section{PENDAHULUAN}

Perubahan iklim memberikan dampak yang besar di berbagai negara. Adapun dampak dari terjadinya perubahan iklim adalah bertambahnya intensitas kejadian cuaca ekstrim di suatu wilayah, perubahan pola hujan, serta peningkatan suhu dan permukaan air laut. Dampak perubahan iklim dapat memengaruhi keadaan di daratan maupun di pesisir atau laut.
Perubahan iklim yang terjadi di daratan dapat memengaruhi pertumbuhan dan produksi tanaman pertanian. Hal serupa juga dapat terjadi di pesisir maupun laut. Perubahan iklim yang terjadi di pesisir atau laut dapat memengaruhi kehidupan organisme di wilayah tersebut.

Salah satu sektor yang terkena dampak dari perubahan iklim adalah sektor perikanan. Seperti yang telah 
dipaparkan sebelumnya bahwa perubahan iklim dapat merusak ekosistem pesisir dan laut. Menurut NOAA (2014), meningkatnya suhu laut dapat membuat terumbu karang mengalami bleaching (pemutihan terumbu karang). Keadaan tersebut terjadi karena zooxanthellae terlepas, sehingga membuat terumbu karang menjadi berwarna putih. Kondisi tersebut menandakan bahwa terumbu karang berada dalam kondisi kritis. Kerusakan terumbu karang diperparah dengan keberadaan manusia yang melakukan perusakan terumbu karang serta penangkapan ikan secara berlebihan. Dengan kejadian itu maka organisme di sekitar terumbu karang juga akan rusak dan dapat pula memengaruhi ketersediaan sumberdaya bagi masyarakat pesisir.

Berbagai macam cara dilakukan untuk mengurangi dampak dari perubahan iklim di daerah pesisir. Menurut artikel dari BBC Indonesia (2012), Kementrian Lingkungan Hidup menggunakan cara adaptasi dan mitigasi dalam menghadapi perubahan iklim di pesisir. Hal serupa ditanggapi oleh CSF, menurut CSF, masyarakat perlu diikutsertakan dengan cara membuat jaringan-jaringan kuat antar masyarakat, sehingga masyarakat dapat melakukan tindakan adaptasi dan mitigasi. Menurut Diposaptono (2011), terdapat upaya mitigasi serta adaptasi yang terkait dengan masyarakat. Masyarakat menjadi aktor penting dalam keberhasilan adaptasi dan mitigasi.

Dalam penelitian Patriana (2011) terdapat dua jenis dampak yang disebabkan oleh perubahan iklim. Kedua dampak tersebut adalah dampak ekologis dan dampak sosial ekonomi. Perubahan ekologis yang terjadi adalah perubahan musim ikan serta kekacauan musim angin. Perubahan musim ikan disebabkan karena adanya kenaikan suhu lautan serta salinitas laut yang berakibat pada perpindahan ikan-ikan. Sementara dampak sosial-ekonomi yang disebabkan oleh perubahan iklim adalah sulitnya menentukan wilayah serta musim penangkapan ikan. Perubahan iklim yang menyebabkan kekacauan cuaca serta perubahan pola migrasi ikan membuat nelayan kesulitan dalam menentukan waktu maupun wilayah yang tepat untuk mencari ikan. Menurut Chen (2008), UNEP (2009), dan Tauli-Corpuz (2008) yang dikutip Patriana (2011), Dampak lain dari perubahan iklim yang berdampak bagi perubahan pada kegiatan produksi nelayan adalah perubahan pola angin.

Salah satu wilayah di Provinsi Jawa Timur yang terkena dampak perubahan iklim yang mengkhawatirkan adalah wilayah Teluk Popoh yang terletak di Desa Besole, Kecamatan Besuki, Kabupaten Tulungagung, Provinsi Jawa Timur. Kerusakan yang terjadi di perairan pantai Sidem berupa perubahan garis pantai yang disebabkan oleh bertambah tingginya permukaan air laut serta adanya aliran sungai Neyama yang langsung bermuara di pantai Sidem, Teluk Popoh. Hal lain yang disebabkan oleh perubahan garis pantai di Teluk Popoh adalah rusaknya sumberdaya alam di perairan Teluk Popoh. Apabila sumberdaya di perairan Teluk Popoh terganggu, maka nelayan dan masyarakat pesisir Teluk Popoh akan semakin sulit untuk mencari ikan di perairan sekitarnya.

Untuk menghindari terjadinya dampak perubahan iklim yang berkelanjutan, maka PJB Brantas melalui PLTA Tulungagung yang beroperasi di wilayah pantai Sidem Teluk Popoh dan pemerintah daerah Tulungagung memberikan inisiatif berupa penanaman pohon dan mangrove di wilayah Pantai Teluk Popoh. Dengan upaya mitigasi tersebut diharapkan mampu mengurangi dampak yang diberikan oleh perubahan iklim di Teluk Popoh. Mitigasi tersebut tidak akan berjalan lancar tanpa adanya usaha adaptasi dari masyarakat sekitar Teluk Popoh, yaitu di Desa Besole, Kecamatan Besuki. Masyarakat di Desa Besole merupakan masyarakat yang didominasi oleh para nelayan yang kehidupannya sangat bergantung pada keberadaan laut. Apabila terjadi perubahan iklim di laut, maka para nelayan dari Desa Besole perlu beradaptasi terhadap perubahaan iklim tersebut.

Kehidupan keseharian nelayan dapat menentukan persepsi mereka terhadap berbagai fenomena yang terjadi di laut serta berbagai permasalahannya. Persepsi ini yang akan memengaruhi tindakan adaptasi yang akan diambil oleh para nelayan. Hal tersebut menarik untuk diteliti bagaimana hubungan antara persepsi nelayan memengaruhi perilaku adaptasi komunitas nelayan Desa Besole terhadap perubahan iklim serta hubungan tindakan dengan persepsi yang dimiliki oleh nelayan. Dari hal tersebut dapat diambil sebuah tindakan adaptasi yang tepat untuk digunakan nelayan di Desa Besole dalam menanggapi keberadaan perubahan iklim.

\section{METODE DAN BAHAN}

Penelitian ini dilaksanakan pada bulan September sampai dengan Desember 2017 di Teluk Popoh Desa Besole Kecamatan Besuki Kabupaten Tulungagung. Data sekunder didapat dari Satuan Kerja Perangkat Daerah (SKPD) terkait di Kabupaten Tulungagung seperti; Dinas Kelautan dan Perikanan, Badan Lingkungan Hidup, Dinas Kehutanan, Dinas Perindustrian dan Perdagangan, Badan Pemberdayaan masyarakat, Bappeda Kabupaten. Sedangkan, data primer didapatkan dari pengamatan lapangan baik yang berada dipesisir maupun didarat. Data primer didapatkan dari observasi lapang, kuesioner, serta wawancara mendalam yang dilakukan kepada responden maupun informanakan diambil di_lapangan dengan melakukan survey kuisoner pada lokasi Teluk Popoh.

\section{Analisis Data}

Dalam penelitian ini data yang diperoleh secara kualitatif maupun kuantitatif diolah untuk selanjutnya dianalisis. Untuk data yang diperoleh melalui metode 
kuantitatif diolah dengan menggunakan Microsoft Excel 2010. Pembuatan tabel tabulasi silang, tabel frekuensi, grafik, dan diagram yang diolah menggunakan aplikasi tersebut. Sementara data kualitatif diolah dengan melakukan reduksi data, penyajian data, dan penarikan kesimpulan. Hal ini bertujuan untuk mendapatkan data yang relevan, sehingga pada akhirnya dapat diambil kesimpulan sesuai penelitian.

\section{HASIL DAN PEMBAHASAN}

\section{Karakteristik Responden}

Presentase responden dalam penelitian ini adalah $89,66 \%$ berjenis kelamin laki-laki dan $10,34 \%$ berjenis kelamin perempuan. Dengan kriteria usia 1112 tahun sebanyak 24,14\%, 21-30 tahun sebanyak $34,48 \%$, 31-40 tahun sebanyak $27,59 \%$ dan $41-50$ tahun sebanyak $13,79 \%$. Dari semua umur responden yang ada, presentase terbanyak terdapat pada responden dengan rentang umur 21-30 tahun. Total kuisioner yang disebar sebanyak 29 buah dimana fokusnya pada nelayan yang sering pergi ke laut. Hal tersebut untuk mengetahui bagaimanakah pandangan masyarakat pesisir terhadap perubahan iklim yang ada di wilayah Teluk Popoh, Jawa Timur.

Hasil kuisoner menunjukkan bahwa pekerjaan masyarakat teluk popoh seperti di tunjukkan pada Tabel 1, adalah nelayan. Hal tersebut menunjukkan bahwa ketika terjadinya perubahan iklim maka akan mengakibatkan dampak yang sangat signifikan terhadap mata pencaharian masyarakat teluk popoh. Selain itu yang terkena dampaknya adalah produsen ikan teri karena mereka tergantung pada hasil tangkapan ikan. Prosentase masyarakat nelayan adalah sebesar 34,48\%. Presentase tersebut setara dengan total sampel responden sebanyak 29 orang. Prosentase mata pecaharian paling sedikit adalah photographer, perangkat desa, produsen ikan teri, service HP, Kepala desa, dan guru.

Tabel 1. Distribusi Mata Pencaharian Masyarakat Teluk Popoh

\begin{tabular}{lcc}
\hline Jenis Pekerjaan & Persen (\%) & $\begin{array}{c}\text { Jumlah } \\
\text { Responden } \\
\text { (orang) }\end{array}$ \\
\hline Ibu Rumah Tangga & 10,34 & 3 \\
Nelayan & 34,48 & 10 \\
Photografer & 3,45 & 1 \\
Perangkat Desa & 3,45 & 1 \\
Produsen Ikan Teri & 3,45 & 1 \\
Service HP & 3,45 & 1 \\
Kontraktor & 6,90 & 2 \\
Kepala Desa & 3,45 & 1 \\
Pelajar & 17,24 & 5 \\
Pedagang & 10,34 & 3 \\
Guru & 3,45 & 1 \\
\hline
\end{tabular}

\section{Klasifikasi Nelayan}

Klasifikasi nelayan diperlukan untuk mengetahui perkembangan ekonomi dan perputaran ekonomi di wilayah Teluk Popoh.

Tabel 2. Klasifikasi Nelayan Teluk Popoh

\begin{tabular}{llcccc}
\hline \multirow{2}{*}{ No. } & Pernyataan & Ya & Ya & Tidak & Tidak \\
\cline { 2 - 5 } & $\mathrm{n}$ & $\%$ & $\mathrm{n}$ & $\%$ \\
\hline 1 & $\begin{array}{l}\text { Apakah } \\
\text { bapak/ibu } \\
\text { memiliki sendiri } \\
\text { perahu untuk } \\
\text { melaut? }\end{array}$ & 10 & 34,48 & 19 & 65.52 \\
\hline 2 & $\begin{array}{l}\text { Apakah } \\
\text { bapak/ibu } \\
\text { memiliki sendiri } \\
\text { jaring untuk } \\
\text { menangkap } \\
\text { ikan? }\end{array}$ & 8 & 27,59 & 21 & 72.41 \\
\hline 3 & $\begin{array}{l}\text { Apakah } \\
\text { bapak/ibu } \\
\text { menyewakan } \\
\text { perahu dan } \\
\text { jaring kepada } \\
\text { orang lain? }\end{array}$ & 2 & 6,90 & 27 & 93.10 \\
\hline 4 & $\begin{array}{l}\text { Apakah } \\
\text { bapak/ibu } \\
\text { mempekerjakan } \\
\text { nelayan lain } \\
\text { untuk melaut? }\end{array}$ & 4 & 13,79 & 25 & 86.21 \\
\hline 5 & $\begin{array}{l}\text { Apakah } \\
\text { bapak/ibu } \\
\text { mendapatkan } \\
\text { penghasilan dari } \\
\text { menyewakan } \\
\text { kapal ke orang } \\
\text { lain? }\end{array}$ & 2 & 6,90 & 27 & 93.10 \\
\hline 6 & $\begin{array}{l}\text { Apakah } \\
\text { bapak/ibu } \\
\text { mengambil } \\
\text { keputusan untuk } \\
\text { melaut? }\end{array}$ & 20 & 68,97 & 9 & 31.03 \\
\hline & & & & \\
\hline
\end{tabular}

Data menunjukkan sebanyak $34,48 \%$ nelayan memiliki kapal sendiri sedangkan sisanya yakni 65,52 $\%$ nelayan masih harus menyewa perahu untuk melaut. Hal yang sama juga terlihat dalam hal kepemilikan jaring, sebanyak 72,41\% harus menyewa jaring atau bagi hasil dengan para pemilik jaring ikan. Walaupun demikian, sangat sedikit nelayan pemilik kapal dan jarring yang bersedia menyewakan perahu dan jaring kapalnya ke nelayan lain. Hanya 6,9\% nelayan yang bersedia menyewakan sedangkan sisanya $93,1 \%$ cenderung melakukan perawatan perahu dan jaring saat tidak melaut. Penangkapan ikan cenderung dilakukan sendiri atau dengan keluarga daripada memperkejakan orang lain. Sebanyak $86,21 \%$ nelayan tidak memperkejakan nelayan lain dalam menangkap ikan sedangkan sisanya sebesar $13,79 \%$ memperkejakan nelayan lain dalam menangkap ikan. 


\section{Tingkat Pengetahuan Masyarakat Terhadap Perubahan Iklim}

Tabel 3. Hasil kuisioner Tingkat Pengetahuan Masyarakat Terhadap Perubahan Iklim

\begin{tabular}{|c|c|c|c|c|c|}
\hline \multirow{2}{*}{ No. } & \multirow{2}{*}{ Pernyataan } & Ya & Tidak & Ya & Tidak \\
\hline & & $\mathrm{n}$ & $\mathrm{n}$ & $\%$ & $\%$ \\
\hline 1 & $\begin{array}{l}\text { Apakah } \\
\text { bapak/ibu pernah } \\
\text { mendengar } \\
\text { istilah perubahan } \\
\text { iklim } \\
\text { sebelumnya? }\end{array}$ & 14 & 15 & 48,28 & 51,72 \\
\hline 2 & $\begin{array}{l}\text { Apakah } \\
\text { bapak/ibu } \\
\text { menganggap } \\
\text { perubahan iklim } \\
\text { itu sedang } \\
\text { terjadi? }\end{array}$ & 12 & 17 & 41,38 & 58,62 \\
\hline 3 & $\begin{array}{l}\text { Apakah } \\
\text { bapak/ibu } \\
\text { mengetahui } \\
\text { bentuk } \\
\text { perubahan iklim } \\
\text { yang terjadi di } \\
\text { sini? }\end{array}$ & 25 & 4 & 86,21 & 13,79 \\
\hline 4 & $\begin{array}{l}\text { Apakah } \\
\text { bapak/ibu } \\
\text { mengetahui } \\
\text { dampak-dampak } \\
\text { yang terjadi dari } \\
\text { perubahan } \\
\text { iklim? }\end{array}$ & 22 & 7 & 75,86 & 24,14 \\
\hline 5 & $\begin{array}{l}\text { Apakah } \\
\text { bapak/ibu } \\
\text { mengetahui } \\
\text { tindakan apa saja } \\
\text { yang dapat } \\
\text { bapak/ibu } \\
\text { gunakan untuk } \\
\text { menghadapi } \\
\text { perubahan } \\
\text { iklim? }\end{array}$ & 7 & 22 & 24,14 & 75,86 \\
\hline
\end{tabular}

Banyak nelayan yang mengaku tidak mengerti apa itu perubahan iklim. Sebanyak 51,72 \% responden mengatakan tidak mengetahui apa itu perubahan iklim akan tetapi 48,28 \% mengatakan sudah pernah mendengar istilah perubahan iklim. Hal tersebut menunjukkan bahwa hampir setengah dari total sampel masyarakat pesisir sudah mengetahui apa itu perubahan iklim. Untuk sekarang 58,62 \% masyarakat tidak menganggap perubahan iklim itu terjadi sedangkan $41,8 \%$ menganggap bahwa perubahan iklim itu sedang terjadi. Hal tersebut berkebalikan dengan pengetahuan masyarakat bentuk perubahan iklim yang terjadi di Teluk Popoh. Sebanyak 86,21\% mengatakan sudah mengetahui bentuk perubahan iklim di Teluk Popoh. Selain itu kebanyakan masyarakat juga mengetahui dampak dampak perubahan iklim dimana data responden menunjukkan $75,86 \%$ masyarakat sudah mengetahui dampak perubahan iklim sedangkan $24,14 \%$ tidak mengetahui dampak perubahan iklim. Dalam melakukan penanganan perubahan iklim masyarakat belum mengetahui tindakan tindakan penanggulangan terjadinya perubahan iklim, hampir 75,86\% responden menyatakan belum mengerti penanganan perubahan iklim secara tepat.

Pengumpulan data reaksi yang dilakukan masyarakat pesisir terhadap perubahan iklim penting untuk dilakukan. Hal tersebut bertujuan untuk mengetahui bagaimana langkap dan kesiapsiagaan masyarakat dalam menghadapi terjadinya perubahan iklim.

Tabel 4. Hasil kuisioner Reaksi Yang Dilakukan Terhadap Perubahan Iklim.

\begin{tabular}{|c|c|c|c|c|c|}
\hline \multirow{2}{*}{ No. } & \multirow{2}{*}{ Pernyataan } & $\mathrm{Ya}$ & Tidak & $\mathrm{Ya}$ & Tidak \\
\hline & & $\mathrm{n}$ & $\mathrm{n}$ & $\%$ & $\%$ \\
\hline 1 & $\begin{array}{l}\text { Setelah } \\
\text { mengetahui } \\
\text { keberadaan } \\
\text { perubahan iklim, } \\
\text { apakah bapak/ibu } \\
\text { siap menghadapi } \\
\text { perubahan iklim? }\end{array}$ & 26 & 3 & 89,66 & 10,34 \\
\hline 2 & $\begin{array}{l}\text { Apakah } \\
\text { bapak/ibu akan } \\
\text { melakukan } \\
\text { tindakan-tindakan } \\
\text { untuk } \\
\text { menghadapi } \\
\text { perubahan iklim? }\end{array}$ & 15 & 14 & 51,72 & 48,28 \\
\hline 3 & $\begin{array}{l}\text { Apakah } \\
\text { bapak/ibu sudah } \\
\text { tahu tindakan apa } \\
\text { saja yang akan } \\
\text { digunakan? }\end{array}$ & 12 & 17 & 41,38 & 58,62 \\
\hline 4 & $\begin{array}{l}\text { Apakah } \\
\text { bapak/ibu sudah } \\
\text { melakukan } \\
\text { tindakan } \\
\text { tersebut? }\end{array}$ & 8 & 21 & 27,59 & 72,41 \\
\hline 5 & $\begin{array}{l}\text { Apakah } \\
\text { bapak/ibu bisa } \\
\text { melanjutkan } \\
\text { tindakan tersebut } \\
\text { secara } \\
\text { berkelanjutan? }\end{array}$ & 8 & 21 & 27,59 & 72,41 \\
\hline
\end{tabular}

Ketika masyarakat sudah mengetahui apa itu perubahan iklim dan dampaknya masyarakat mengatakan siap apabila terjadi dampak perubahan iklim yang terjadi di Teluk Popoh. Sebanyak $89.66 \%$ data responden mengatakan siap dalam menghadapi adanya perubahan iklim sedangkan sisanya $10.34 \%$ mengatakan tidak siap apabila terjadi perubahan iklim. Sejauh ini hanya setengah dari total responden mengatakan sudah melakukan tindakan tindakan dalam penanggulangan dampak perubahan iklim, akan tetapi $58.62 \%$ responden belum mengetahui tindakan apa saja dalam menanggulangi dampak perubahan iklim, sedangkan sisanya 27.59 mengetahui tindakan yang harus dilakukan dalam menangani perubahan iklim. Sebanyak $72.41 \%$ responden mengatakan 
bahwa tidak yakin bahwa tindakan tindakan tersebut bisa dilaksanakan secara berkelanjutan akan tetapi $27.59 \%$ mengatakan yakin bahwa tindakan penanggulangan perubahan iklim akan dilaksanakan secara berkelanjutan.

\section{Persepsi NelayanTerhadapPerubahan Iklim}

Identifikasi persepsi nelayan terhadap perubahan iklim diperlukan untuk mengetahui sejauh mana masyarakat merasakan dampak atau pengetahuan dasar mengenai perubahan iklim.

Tabel 3. Hasil Kuisioner Persepsi nelayan Terhadap Perubahan Iklim

\begin{tabular}{|c|c|c|c|c|c|}
\hline \multirow{2}{*}{ No. } & \multirow{2}{*}{ Pernyataan } & Ya & $\mathrm{Ya}$ & Tidak & Tidak \\
\hline & & $\mathrm{n}$ & $\%$ & $\mathrm{n}$ & $\%$ \\
\hline 1 & $\begin{array}{l}\text { Apakah } \\
\text { bapak/ibu } \\
\text { merasakan } \\
\text { dampak } \\
\text { perubahan } \\
\text { iklim? }\end{array}$ & 22 & 75,86 & 7 & 24,14 \\
\hline 2 & $\begin{array}{l}\text { Apakah } \\
\text { bapak/ibu } \\
\text { merasakan } \\
\text { dampak } \\
\text { perubahan } \\
\text { iklim } \\
\text { mengubah } \\
\text { kehidupan } \\
\text { bapak/ibu? }\end{array}$ & 10 & 34,48 & 19 & 65,52 \\
\hline 3 & $\begin{array}{l}\text { Apakah } \\
\text { dampak } \\
\text { perubahan } \\
\text { iklim } \\
\text { menjadikan } \\
\text { kehidupan } \\
\text { bapak/ibu } \\
\text { lebih baik? }\end{array}$ & 4 & 13,79 & 25 & 86,21 \\
\hline 4 & $\begin{array}{l}\text { Apakah } \\
\text { dampak } \\
\text { perubahan } \\
\text { iklim } \\
\text { mengubah } \\
\text { keadaan } \\
\text { lingkungan } \\
\text { sekitar rumah } \\
\text { bapak/ibu? }\end{array}$ & 17 & 58,62 & 12 & 41,38 \\
\hline 5 & $\begin{array}{l}\text { Apakah } \\
\text { dampak } \\
\text { perubahan } \\
\text { iklim } \\
\text { mengubah } \\
\text { cara-cara } \\
\text { bapak/ibu } \\
\text { dalam mencari } \\
\text { nafkah? }\end{array}$ & 7 & 24,14 & 22 & 75,86 \\
\hline
\end{tabular}

Perubahan iklim yang terjadi di dunia telah berpengaruh langsung terhadap perubahan iklim di Teluk Popoh. Sebagian besar nelayan mengaku merasakan dampak perubahan iklim sedangkan sisanya tidak merasakan hal yang sama. Meskipun demikian, sebagian besar nelayan menganggap perubahan iklim tidak berpengaruh pada kehidupan keluarga maupun sosial mereka. Hasil survei menunjukkan bahwa sebagaian besar nelayan merasakan perubahan iklim memberikan pengaruh negatif pada kehidupan nelayan dan keadaan lingkungan sekitar rumah. Sementara sebagiannya lagi mengaku tidak merasakan adanya perubahan lingkungan disekitar rumah mereka. Para nelayan mengakui, meskipun perubahan iklim berdampak negative terhadap mata pencaharian mereka tetapi mereka tidak akan mengubah mata pencaharian dan tidak mengubah cara mereka dalam menangkap ikan.

\section{Tindakan Adaptasi Nelayan}

Pengumpulan data tindakan adaptasi nelayan terhadap perubahan iklim untuk mengetahui seberapa jauh masyarakat pesisir utamanya nelayan dalam mempersiapkan tindakan yang diperlukan dalam menghadapi perubahan iklim.

Tabel 5. Tindakan Adaptasi Nelayan

\begin{tabular}{|c|c|c|c|c|c|}
\hline \multirow{2}{*}{ No. } & \multirow{2}{*}{ Pernyataan } & Ya & Tidak & $\mathrm{Ya}$ & Tidak \\
\hline & & $\mathrm{n}$ & $\mathrm{n}$ & $\%$ & $\%$ \\
\hline 1 & $\begin{array}{l}\text { Apakah bapak/ibu } \\
\text { akan menghadapi } \\
\text { perubahan iklim } \\
\text { yang terjadi? }\end{array}$ & 27 & 2 & 93,10 & 6,90 \\
\hline 2 & $\begin{array}{l}\text { Apakah tindakan } \\
\text { yang digunakan } \\
\text { oleh bapak/ibu } \\
\text { adalah tindakan } \\
\text { yang } \\
\text { berkelanjutan? }\end{array}$ & 8 & 21 & 27,59 & 72,41 \\
\hline 3 & $\begin{array}{l}\text { Apakah bapak/ibu } \\
\text { akan mencari } \\
\text { tindakan yang } \\
\text { dapat mengurangi } \\
\text { dampak perubahan } \\
\text { iklim? }\end{array}$ & 12 & 17 & 41,38 & 58,62 \\
\hline 4 & $\begin{array}{l}\text { Apakah bapak/ibu } \\
\text { lakukan akan } \\
\text { menyesuaikan } \\
\text { dengan dampak } \\
\text { perubahan iklim } \\
\text { yang dirasakan? }\end{array}$ & 13 & 16 & 44,83 & 55,17 \\
\hline 5 & $\begin{array}{l}\text { Apakah bapak/ibu } \\
\text { akan berusaha } \\
\text { untuk dapat } \\
\text { mejaga } \\
\text { kelangsungan } \\
\text { kehidupan } \\
\text { bapak/ibu di sini? }\end{array}$ & 29 & 0 & 100,00 & 0,00 \\
\hline 6 & $\begin{array}{l}\text { Apakah bapak/ibu } \\
\text { melakukan } \\
\text { tindakan baru yang } \\
\text { dirasa lebih baik } \\
\text { dari tindakan yang } \\
\text { sebelumnya } \\
\text { dilakukan? }\end{array}$ & 11 & 18 & 37,93 & 62,07 \\
\hline
\end{tabular}


Hasil kuisioner yang telah disebar mengenai tindakan adaptasi nelayan menunjukkan bahwa $93,1 \%$ nelayan akan menghadapi perubahan iklim yang akan terjadi sedangkan sisanya $6,9 \%$ mengatakan tidak akan menghadapi perubahan iklim. Akan tetapi para responden mengatakan bahwa $72,41 \%$ tidak yakin bahwa tindakan penanggulangan perubahan iklim adalah tindakan yang berkelanjutan akan tetapi 27,59\% mengatakan bahwa yakin tindakan tersebut yakin akan menjadi berkelanjutan. Hampir setengah dari responden mengatakan tidak akan mencari solusi dalam menangani perubahan iklim karena keterbatasan ilmu pengetahuan dan wawasan yang luas. Sebanyak 55,17\% nelayan mengatkan tidak akan menyesuaikan kegiatan mereka dengan adanya perubahan iklim sedangkan $44,83 \%$ akan menyesuaikan kegiatan dengan terjadinya dampak perubahan iklim. Responden sepakat bahwa mereka akan menjadi kelangsungan hidup mereka di Teluk Popoh apapun yang terjadi. Kecenderungan masyarakat pesisir tidak melakukan tindakan baru yang dimana dirasa memperbarui tindakan sebelumnya. Sebanyak $62,07 \%$ mengatakan tidak adanya tindakan baru yang membawa dampak lebih baik dan 37,93 mengatakan sebaliknya.

\section{KESIMPULAN}

Berdasarkan hasil penelitian ini dapat disimpulkan sebagai berikut :

1. Karakteristikresponden menunjukkan bahwa sebagian bermata pencaharian sebagai nelayan dengan kisaran umur paling banyak adalah 2130 Tahun. Tingkat pendidikan paling banyak adalah tamat SD. Kebanyakan lama tinggal responden di Teluk Popoh adalah 21-30 Tahun.

2. Karateristik nelayan di Teluk Popoh kebanyakan tidak mempunyai kapal dan jaring sendiri dalam menangkap ikan. Selain itu kebanyak nelayan dalam menangkap ikan tidak memperkejakan nelayan lainnya karena lebih mengehemat biaya pengeluaran nelayan.

3. Persepsi nelayan dalam terjadinya perubahan iklim sebagian besar sudah merasakan dampak yang cukup terasa pada lingkungan mereka. Akan tetapi para responden belum mengetahui bagaimanakah cara penanggulangan yang tepat dalam menanggulangi terjadinya dampak perubahan iklim. Selain itu masyarakat juga kurang yakin setiap tindakan dalam menanggulangi perubahan iklim akan dapat dilakukan secara berkelanjutan

\section{UCAPAN TERIMA KASIH}

Terima kasih kepada Badan Penelitian Dan Pengabdian Masyarakat Fakultas Perikanan Dan Ilmu Kelautan Universitas Brawijaya, dan CORECT Universitas Brawijaya beserta seluruh Tim Peneliti yang telah banyak membantu baik dari segi pendanaan maupun dalam bentuk bantuan lainnya sehingga penelitian ini dapat terlaksana dengan baik.

\section{DAFTAR PUSTAKA}

[BBC Indonesia] British Broadcasting Corporation in Indonesia. 2012. Kampung Iklim untuk turunkan emisi [internet]. [dikutip 18 Februari 2014]. Dapat diunduh dari http://www.bbc.co.uk/indonesia/berita_indones ia/2012/05/120515_kampungiklim.shtml

[NOAA] National Oceanic and Atmospheric Administration. 2014. What is Coral Bleaching? [internet]. [dikutip 20 Maret 2014]. Dapat diunduh dari http://oceanservice.noaa.gov/facts/coral_bleach .html

Diposaptono S. 2011. Sebuah Kumpulan Pemikiran :MitigasiBencana dan Adaptasi Perubahan Iklim (GempaBumi, Tsunami, Banjir, Abrasi, Pemanasan Global, dan Semburan Lumpur Lapindo). Jakarta [ID]: KementrianKelautan dan Perikanan. 192 hal.

Patriana R. 2011. Pola Adaptasi Nelayan Terhadap Perubahan Iklim (Studi Kasus Nelayan Dusun Ciawitali, Desa Pamotan, Kecamatan Kalipucang, Kabupaten Ciamis, Jawa Barat) [skripsi]. Bogor [ID]:Institut Pertanian Bogor. 128

hal. 